\title{
TEORIA DA DIVISÃO DOS PODERES: antecedentes históricos e principais aspectos
}

THEORY OF THE DIVISION OF THE POWERS: historical background and key aspects

\author{
Eduardo Domingos Bottallo ${ }^{1}$
}

\begin{abstract}
Resumo:
O objetivo do estudo é analisar os antecedentes históricos, na Inglaterra e na França, da teoria de divisão dos poderes, bem como examinar as características jurídicas fundamentais dessa teoria.

Palavras-chave: Poderes do Estado. Legislativo. Executivo. Judiciário.

Abstract:

The objective of this study is to analyze the historical background, in England and France, of the Theory of the Division of Power, and also to examine the fundamental juridical characteristics of such theory.
\end{abstract}

Keywords: Powers of State. Legislature. Executive. Judiciary.

1. As origens históricas do Instituto

1.1. Já vislumbrada, em seu conceito fundamental, por filósofos e estudiosos da arte política da antigüidade e da idade média, é, entretanto, na era moderna, mercê da obra de Locke e, sobretudo, de Montesquieu, que a teoria da divisão dos poderes se projeta na plenitude de seu significado técnico e de seu notável valor jurídico

Assim, quando nos propomos a traçar as origens históricas desta teoria, pretendemos limitar nosso campo de estudos à apreciação das instituições políticas, econômicas, sociais e religiosas da Inglaterra e França nos séculos XVII e XVIII, pela convicção de que se encontram nos desacertos das mesmas, as causas diretas e imediatas que não-só deram origem como tornaram verdadeiramente imperiosa a formulação da doutrina, objeto de nosso interesse.

\footnotetext{
1 Professor Associado do Departamento de Filosofia e Teoria Geral do Direito da Faculdade de Direito da Universidade de São Paulo.
} 


\subsection{O Absolutismo na Inglaterra nos primórdios do século XVII}

Quando a Rainha Elizabeth I, última descendente da Casa dos Tudors, assumiu o trono da Inglaterra, o governo parlamentar que vigorava neste País era uma mera ficção.

O Parlamento era convocado, como simples formalidade, somente quando o soberano pretendia decretar medidas de aceitação duvidosa, ou então quando o utilizava para mascarar, com o rótulo de "concessões voluntárias dos representantes do povo", as desapropriações e outras medidas tendentes a robustecer os proventos da Coroa.

O pseudopoder legislativo corporificado no Parlamento prestava-se, desta forma, a quase tudo: suas convocações eram irregulares e as legislaturas desenvolviam-se por períodos muitos breves; a interferência do trono nas eleições fazia com que as duas câmaras parlamentares fossem preenchidas quase que exclusivamente por bajuladores; todos os instrumentos eram válidos para o soberano obter o apoio do órgão representativo, desde a adulação e o suborno, até o engodo e a ameaça.

Assim a manutenção do Parlamento não se justifica a não ser como astuta manobra do soberano para disfarçar seu absolutismo.

Com a morte de Elizabeth, em 1603, assumiu o poder o Rei James I (antes James VI da Escócia), primeiro monarca inglês da Casa dos Stuarts e fundador da última dinastia absolutista da Inglaterra.

Conforme salienta Edward McNall Burns "James I, embora gostasse de ser adulado com o título de Salomão Inglês pelos seus cortesãos, não teve sequer o bom senso de contentar-se, como seus predecessores Tudors, com o poder absoluto de fato, fazendo questão de tê-lo também de direito. Fez sua a doutrina francesa do direito divino dos reis". 2

Como é evidente, essa pretensão à autoridade divina, exteriorizada sem as sutilezas e hábeis maquinações dos Tudors, despertou profunda oposição do povo inglês, ainda não, de todo, esquecido do ideal feudal de um governo limitado do qual era expressão a Magna Carta. Não bastasse tal circunstância, a política de James I era de molde a despertar o antagonismo até nos seus súditos mais leais: insistia em criar impostos ou aumentá-los, através de atos não submetidos ao Parlamento; interferia na liberdade de comércio concedendo monopólios e extravagantes privilégios a companhias protegidas; conduzia as relações exteriores ao sabor de suas conveniências pessoais sem levar em conta os interesses econômicos de alguns dos mais poderosos cidadãos, exemplo típico

\footnotetext{
2 BURNS, Edward McNall. História da civilização ocidental. Porto Alegre: Ed. Globo, 1959. p. 523.
} 
do que foi o acordo concentrado com a Espanha que, ao mesmo tempo, pôs fim à guerra iniciada durante o Reinado de Elizabeth e ao propósito de forte grupo de comerciantes ingleses de destruir o grande império colonial tutelado pela Corte ibérica.

Paralelamente, James I negava à Câmara dos Comuns não-só o reconhecimento dos poderes de seus membros, como também suas imunidades, isto é, a própria liberdade de opinião expedida no decorrer dos debates. Para ele, tais franquias representavam favores que podiam ser revogados e não direitos inerentes ao próprio sistema de Governo inglês, conforme lhe tentaram fazer ver os comuns no chamado grande protesto de 1621 que o Rei, com suas próprias mãos, apagou das atas, dissolvendo em seguida o Parlamento e prendendo vários de seus membros.

Também a intolerância religiosa de James, anglicano fanático, causou profundos ressentimentos, lançando, no conjunto dessas circunstâncias, as sementes do conflito irreprimível que, pouco depois, iria abalar os alicerces de todo o Império britânico.

\subsection{A petição de direitos de 1628}

O sucessor de James I foi seu filho Carlos I que alimentava as mesmas idéias pretensiosas acerca do poder real. Em face disto, logo tiveram início suas desavenças com os líderes da oposição parlamentar. O cerne desses atritos residia em questão de natureza tributária: necessitando urgentemente de dinheiro para custear uma guerra em que se havia envolvido com a França, e encontrando séria resistência parlamentar para obtenção das respectivas verbas, Carlos I tratou de obter numerário através de extorsões feitas à burguesia (as chamadas "benevolências"), bem como de empréstimos forçados, prendendo e encarcerando, sem processo, os que se recusavam a ceder às pressões.

A reação a tais arbitrariedades foi à famosa Petição de Direitos imposta pelos líderes parlamentares ao monarca, em 1628, na qual eram taxadas de ilegais as prisões arbitrárias e o abotelamento de soldados em casas particulares, proibidos os impostos cobrados sem aprovação do Parlamento e vedada a decretação da lei marcial em tempo de paz.

\subsection{As causas do desencadeamento da Revolução Puritana}

Aprovação não significa, contudo, aplicação e Carlos I, em pouco, não-só violava os seus compromissos como também - apoiando-se nos conselhos do conde de Straford, do arcebispo de Cantebury Laud e em tribunais iníqüos, arbitrários e subservientes 
-, dissolvia o Parlamento, restaurava leis feudais obsoletas, cobrando multas de todos que as violavam, obrigava os ricos a solicitarem o título de Cavaleiro mediante pagamento de gordas taxas, vendia monopólios a preços exorbitantes e determinava aos juízes que elevassem as custas dos processos criminais.

Entretanto, o mais desastrado e impopular de todos os expedientes de que Carlos I lançou mão para conseguir dinheiro foi a chamada "contribuição naval" (ship money). De acordo com um antigo costume, as cidades costeiras deviam contribuir com navios para a armada real. Como as necessidades da armada fossem atendidas por outros meios, o Rei entendeu que estas cidades - e também as do interior - deveriam passar a contribuir com dinheiro. Tais exigências irritaram particularmente a classe média e serviram para robustecer a oposição desse grupo à tirania monárquica.

Não menos desastrada foi a ação de Carlos I no plano religioso. Após descontentar os calvinistas com a nomeação de William Laud, clérigo de nítidas simpatias pela "Igreja Alta" anglicana, para arcebispo de Canterbury, ultrajou o sabatismo dos puritanos ao autorizar jogos públicos aos domingos. Pior ainda, tentou impor o sistema episcopal de governo da igreja aos presbiterianos escoceses que eram calvinistas ainda mais fanáticos do que os puritanos ingleses.

A conseqüência dessa última determinação foi uma sublevação armada pela qual os escoceses, bem adestrados militarmente-em razão de serviços prestados a exércitos mercenários de outros países -, apossaram-se de toda região norte da Inglaterra.

\subsection{O Grande Parlamento}

A sublevação escocesa selou o destino de Carlos I e também do absolutismo monárquico inglês.

Com efeito, para obter dinheiro destinado a custear a punição da resistência escocesa, Carlos I foi obrigado a convocar o Parlamento, em 1640, após onze anos de regime autocrático, colocando-se, com esse ato, nas mãos de seus adversários.

Conscientes de sua força, os parlamentares exigiram as cabeças de Strafford e Laud a quem atribuíam a maior parcela de responsabilidade pelo Estado de calamidade pública em que se encontrava o país; proibiram o monarca de dissolver o Parlamento, prescrevendo, ao mesmo tempo, que este se reunisse em sessão pelo menos uma vez a cada três anos; aboliram as contribuições navais e os tribunais especiais que tinham servido como instrumento da tirania. 
Ao que considerava uma violação de suas prerrogativas, Carlos I tentou ainda responder com uma demonstração de força, invadindo com a sua guarda a Câmara dos Comuns com o propósito de prender cinco dos seus principais líderes. Todos escaparam, mas ficara profundamente cavado o abismo entre o Rei e o Parlamento, tornando inevitável a luta aberta.

\subsection{A Revolução Puritana}

Deflagrada a guerra civil, que durante seis anos iria banhar de sangue o solo inglês, logo se delinearam as facções em litígio: de um lado, os realistas ou cavaliers, constituídos sobretudo pela nobreza e o clero, e, de outro, os roundheads, abrangendo a burguesia urbana, grande parte dos gentry ou fidalgos rurais, além de alguns nobres descontentes e os yeomanry, milícia montada dos pequenos proprietários.

Apesar das vitórias iniciais dos realistas, seu exército, frouxo e licencioso, não poderia opor decidida resistência ao do Parlamento, composto por presbiterianos radicais, reformadores republicanos e moderados constitucionais, em que animava uns o sopro religioso, outros o ressentimento e outros ainda o sincero desejo de reforma.

Do seio do Exército parlamentar, despontava então a figura de Oliver Cromwell, líder dos ironsides, regimento famoso por sua invulgar disposição de luta, disciplinado que era por oficiais que deviam suas patentes, menos à posição social, e mais à competência profíssional e às arraigadas convicções puritanas de seus integrantes.

Derrotado em Naseby, Carlos I procurou refúgio na Escócia, onde, contudo, ao invés de encontrar ambiente de fidelidade à sua casa, viu-se presa do fervor calvinista que ali imperava, sendo, em conseqüência, entregue ao Parlamento britânico.

\subsection{O Regime de Cromwell}

Era o Parlamento, em sua maioria, partidário da reposição do Rei ao trono, mediante compromisso de sua parte. Todavia, aproveitando-se das dissensões internas, Cromwell reuniu em torno de si uma minoria de puritanos extremados, conhecidos como "independentes" e recorreu a uma solução de força, excluindo dos comuns todos quantos eram favoráveis àquela política de reconciliação. Cento e cinqüenta e três parlamentares foram expurgados e os cinqüenta e poucos remanescentes, todos homens de confiança de Cromwell, atribuíram-se poderes legislativos. Em conseqüência, o Rei foi pronunciado como incurso em crime de alta traição, julgado por uma Corte de justiça especial, composta por cento e trinta e cinco membros e condenado à morte em 1649. 
Seguiram-se o estabelecimento, pelos comuns, de uma República (commonwealth) - para a qual o país nem estava preparado, nem convictamente desejava -, a abolição da Câmara dos Lords, e a instituição de um Conselho de Estado composto por quarenta e um membros, investido nas funções de Poder Executivo.

Tal foi, com efeito, a mudança realmente fundamental ocorrida na organização do sistema de Governo inglês. Todavia, sua vida foi efêmera. Em 1653, Cromwell, contando com o maciço apoio do Exército e exasperado pela tentativa de seus legisladores de perpetuarem-se no poder e aproveitarem-se do confisco da fortuna de seus inimigos, invadiu o Parlamento - então conhecido como rump parliamen - com um destacamento de tropas e ordenou a seus membros que se dispersassem.

A ditadura virtual que se seguiu teve como base um "instrumento de governo" editado pelo Exército, no qual, além de amplos poderes, era outorgado a Cromwell o título de "lord protetor", vitalício e hereditário.

Durante os primeiros tempos de seu governo, Cromwell ainda permitiu a existência de um Parlamento de autoridade limitada, eleito em 1654. Mas logo foram seus membros demitidos, sob fundamento de que "o Senhor Jeová já não necessitava de seus serviços". 3

Oliveira Lima, para destacar o caráter transitório do regime de Cromwell, salienta:

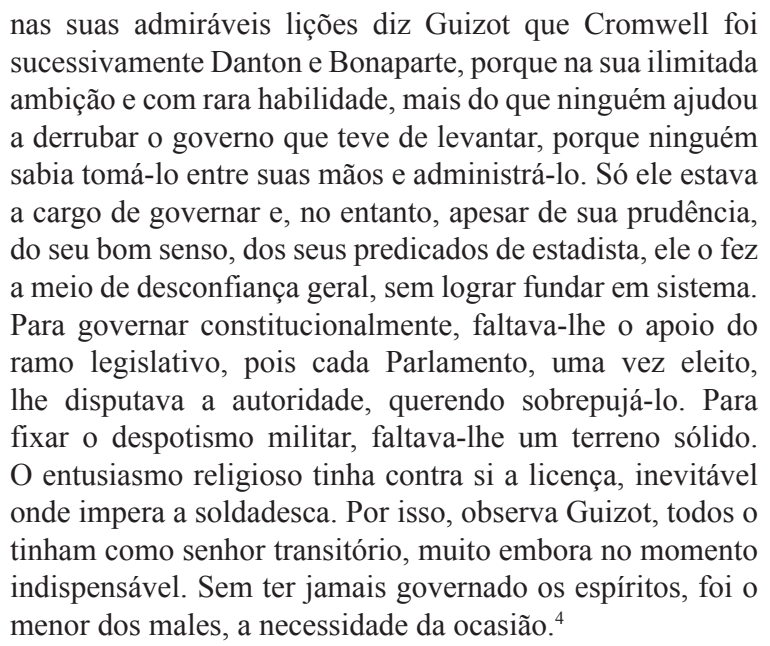

3 Cf. BURNS, Edward McNall. História da civilização odicental. 2. ed. Porto Alegre: Ed. Globo, 1959. p. 527.

4 LIMA, Oliveira. História da civilização. São Paulo: Melhoramentos, s.d. p. 299. 


\subsection{A restauração}

Com a morte de Cromwell, o regime que ele havia instituído, baseado fundamentalmente em seus predicados pessoais e na natureza autocrática de seu temperamento, também morreu. Ricardo Cromwell não chegou a vestir por mais de seis meses a vestimenta despótica que seu pai lhe legara, menos pela tibieza de seu caráter e mais porque nem a República nem o protetorado jamais haviam tido o apoio da maioria do povo inglês.

Desta forma, o convite ao príncipe Carlos para reassumir o trono ocupado por seu pai, formulado por um Parlamento recém-eleito, foi recebido com júbilo geral, particularmente aumentado pela disposição manifestada pelo novo monarca em não-reinar como déspota, mas sim respeitar o Parlamento e os princípios da Magna Carta.

A crença de que a Nação poderia reencontrar sua antiga estabilidade, e bem assim a lembrança da experiência amarga a que o povo inglês havia sido submetido desde a guerra civil, fizeram com que os grandes problemas de ordem política e religiosa, conquanto não definitivamente resolvidos, fossem contemporizados até 1688, quando, já no Reinado de James II - que três anos antes havia sucedido seu irmão Carlos I -, explodiram outra vez, dando origem à chamada Revolução Gloriosa.

\subsection{A Revolução Gloriosa e o fim do Absolutismo inglês}

O estopim que reacendeu os velhos antagonismos foi a determinação de James II em fazer o trono da Inglaterra - católico declarado que era - retornar à órbita de influência da igreja de Roma.

Sua deposição, ocorrida em 1689, deu-se sem a necessidade de ser disparado um único tiro e a Coroa foi oferecida, em conjunto, ao príncipe holandês Guilherme de Orange e à sua esposa Maria, filha mais velha de James II.

No decorrer do ano de 1689, o Parlamento aprovou numerosas leis destinadas a salvaguardar os direitos dos cidadãos e a proteger suas próprias prerrogativas contra as intromissões da Coroa.

A primeira dessas leis prescrevia o princípio da fixação anual das verbas do tesouro, modificando o critério anterior por força do qual a receita ordinária do erário era concedida ao monarca, em caráter vitalício, no início de cada reinado.

A seguir, o Parlamento aprovou o Toleraction Act, concedendo liberdade religiosa a todos os cidadãos, menos aos católicos. Por fim, em 16 de dezembro de 1689 , foi aprovado o famoso Bill of Rigths que, entre outras disposições, garantia aos cidadãos 
julgamento por júri popular (ressalvando, ainda, o direito de apelação ao governo em casos de injustiça), condenava as fianças excessivas, as punições cruéis e as multas exorbitantes, e proibia o Rei de suspender a execução das leis ou de lançar impostos sem autorização parlamentar.

Para realçar o significado da Revolução Gloriosa, bem significativa é a seguinte passagem de Burns:

seria quase impossível exagerar o significado da revolução de 1688-89. Assinalando o triunfo final do Parlamento sobre o rei, punha termo definitivamente à monarquia absoluta na Inglaterra. Nunca mais uma cabeça coroada desafiaria, naquele país, o legislativo, como fizeram os Stuarts, nem mesmo Jorge III, celebrizado pela lenda da América colonial como 'aquela besta do rei inglês'. A revolução também desferiu golpe de morte na teoria do direito divino dos reis. Teria sido impossível a Guilherme e Maria negar o fato de haverem recebido a coroa do Parlamento. E a autoridade deste para determinar quem deveria ser o rei ainda foi robustecida pela aprovação do act of settlement, em 1701. Essa lei estatuía que, com a morte de Ana, irmã mais moça de Maria, a coroa caberia à eleitora Sofia de Hanover ou a qualquer dos seus herdeiros que fosse protestante. Havia cerca de quarenta pessoas com melhores credenciais para o trono do que Sofia, mas foram arbitrariamente eliminadas pelo Parlamento por serem católicas. Por fim, a revolução gloriosa muito contribuiu para as revoluções americana e francesa dos fins do século XVIII. O exemplo dos ingleses, pondo por terra o governo absoluto, valeu como poderosa inspiração aos inimigos do despotismo em outras terras. Foi o ideal revolucionário inglês de um governo limitado que forneceu a essência da teoria política de Voltaire, Jefferson e Paine. E uma porção considerável do Bill of rigths foi incorporada à Declaração dos Direitos do Homem, em 1789 na França e às dez primeiras emendas à Constituição americana. $^{5}$

\subsection{A monarquia Absolutista da França}

Em 1624, sob o Reinado de Luiz XIII, os negócios do Reino da França foram confiados ao cardeal Richelieu que logo deixou claro quais seriam os objetivos a cuja consecução inexoravelmente se dedicaria: a destruição de todas as limitações ao poder real e a conversão da França na mais poderosa nação da Europa.

5 BURNS, Edward McNall. História da civilização odicental. 2. ed. Porto Alegre: Ed. Globo, 1959. p. 529530 . 
Para atingir o primeiro desses propósitos, Richelieu despiu os Estados Gerais das funções legislativas que lhes incumbia, atribuindo-as a um órgão denominado Grande Conselho ou Conselho de Estado que passou a elaborar, sob sua direta orientação, as ordenações necessárias à administração nacional.

Aliás, esses Estados Gerais, que constituíam um arremedo de legislativo dentro da monarquia absolutista francesa, jamais foram capazes de personificar a vontade popular. Ainda em Oliveira Lima podemos ler o lamentável retrato do organismo: "eram assim os estados gerais um mero instrumento da Coroa, chamados a deliberar pelo capricho dos reis, visto que, com sua falta de protesto, tinham autorizado o estabelecimento dos impostos permanentes. O Parlamento de Paris, posto que se manifestasse contrário ao arbitrio em matéria de impostos e de justiça e cercasse de algumas garantias a liberdade individual, não personificava a nação. Seus cargos eram venais e não constituía ele um corpo legislativo". ${ }^{6}$

Foi também de Richelieu a idéia de estabelecer um sistema, sob o qual intendentes ou agentes do Rei se encarregavam das administrações locais, com a finalidade de centralizar na Coroa o governo de toda nação. Quando o cardeal morreu, em 1642, o caminho para o despotismo monárquico estava quase que totalmente aplainado.

\subsection{Os Bourbons}

\section{Relata McNall Burns:}

A monarquia absoluta na França atingiu o zênite no reinado dos três últimos reis Bourbons, antes da revolução. O primeiro desses três monarcas foi Luis XIV (1643-1715), que encarnou, mais do que qualquer outro soberano de sua época, o ideal do absolutismo. Orgulhoso, extravagante e autoritário, Luis nutria as idéias mais exaltadas possíveis acerca de sua posição de rei. Não-só acreditava ter recebido de Deus o encargo de reinar mas para ele, a sorte do Estado estava intimamente ligada à sua própria pessoa. A famosa frase que lhe é atribuída - l'état c'est moi - talvez não seja textualmente exata, mas exprime com toda clareza a concepção que ele fazia de sua autoridade. ${ }^{7}$

Na verdade, o retrato da França era, nessa época, dos mais lamentáveis. País com vinte e cinco milhões de habitantes, apenas cerca de dez por cento desta população, constituída por nobres e clérigos, detinha a propriedade de mais da metade do solo

\footnotetext{
${ }_{6}$ BURNS, Edward McNall. História da civilização odicental. 2. ed. Porto Alegre: Ed. Globo, 1959. p. 303.

7 Id. Ibid., p. 532.
} 
territorial e de um quarto da receita originária das pensões e sinecuras cobradas das classes camponesas.

Nas cidades florescia uma pequena burguesia desfrutando de razoável prosperidade econômica, mas completamente marginalizada do processo político. A falta de um Parlamento moderador efetivo deixava a liberdade individual à mercê do arbítrio do Rei e de seus funcionários, quase sempre brutais, corruptos e despreparados para exercer funções de autoridade.

Havia notória desigualdade tributária entre as classes, e as guerras - por vezes inúteis, mas sempre sangrentas e onerosas - em que se empenhava o monarca tinham de ser custeados exatamente pela classes despidas de qualquer poder de interferência, direta ou indireta, nos negócios do governo, como sejam o campesinato e a pequena e média burguesia urbana.

\subsection{Os antecedentes da Revolução de 1789}

Dentro desse panorama, nada mais natural que a onda de reação verificada a partir da segunda metade do século XVIII, reação essa preliminarmente limitada ao campo das idéias e posteriormente materializada na revolução armada de 1789.

Assim, se o princípio econômico dominante era o mercantilismo que propugnava o favorecimento da balança de comércio com o Exterior, surgiu, em oposição, a idéia fisiocrata que via na agricultura a primordial e mais importante fonte de riquezas; se, no plano político, o regime era despótico e o Rei se dizia mandatário de Deus e, portanto, inatingível em sua majestade, grande receptividade tinham as idéias liberais inglesas cultivadas por Bacon, Newton, Locke e muitos outros, cujas sementes encontravam em Voltaire, Montesquieu, Rousseau, nos enciclopedistas Diderot e d'Alembert terreno profícuo ao seu desenvolvimento.

Os desmandos de Luis XV e Luis XVI, dignos sucessores, conquanto muito mais medíocres, do "Rei Sol" tornaram inevitável o movimento de 1789, precedido que fora, como já dito, da grande renovação filosófica e cultural processada em França, a partir de 1750 .

$\mathrm{Na}$ verdade, os últimos reis absolutistas da França, por suas ridículas pretensões de poder, dificilmente teriam conseguido melhor êxito, se tivessem o propósito deliberado de tornar inevitável a revolução. 
2. A concepção da teoria da divisão dos poderes

2.1. O pensamento de John Locke

Embora não escondendo, em sua obra, a influência marcante de John Milton, James Harrington, Blackstone e outros pensadores liberais ingleses seus contemporâneos, John Locke pode ser considerado como o grande teórico das doutrinas políticas liberais dos séculos XVII e XVIII.

Sua filosofia política está exposta no Segundo Tratado de Direito Civil, publicado em 1690, onde desenvolve uma teoria de governo limitado através da qual buscava justificar o regime parlamentar britânico estabelecido após a Revolução Gloriosa.

Partindo da idéia de que os homens viviam originariamente num estado natural, sem encontrar barreiras à sua liberdade e sem limitações por qualquer espécie de governo, Locke sustentava que a convenção dos indivíduos no sentido de estabelecer uma sociedade civil, instituir um governo e atribuir-lhe certos poderes, objetivava preservar e garantir essa mesma liberdade. Assim, a única finalidade do Estado era zelar pela aplicação e observância da lei natural.

Uma vez que o Estado nada mais é que o poder conjunto de todos os membros da sociedade, sua atividade - sustentava - "não pode ser maior do que aquela que essas pessoas saíam em estado natural, antes de formarem um grupo social e de cederem-na à comunidade". ${ }^{.}$

As idéias políticas de Locke refletiram as novas tendências do Direito Natural manifestadas em fins do século XVII, quando filósofos e juristas procuravam transformar o Direito em um instrumento primordialmente destinado a evitar a autocracia e o despotismo. Com efeito, a ascensão de governos absolutistas em quase todos os países da Europa tornara evidente o quanto era importante opor um escudo protetor das liberdades individuais contra intromissões do Estado. Assim o Direito Natural, dentro da nova tendência acima referida, passa a dar ao problema da liberdade a mesma importância que, em um estágio anterior, havia dedicado àquele da segurança do ordenamento jurídico.

De fato, para Locke todos os direitos, que não os expressamente cedidos, ficavam reservados às próprias pessoas. "O direito natural - dizia - permanece como norma eterna para todos os homens".

\footnotetext{
8 BURNS, Edward McNall. História da civilização odicental. 2. ed. Porto Alegre: Ed. Globo, 1959. p. 598.
} 
No sistema de governo por ele traçado, o Poder Legislativo, embora superior ao Executivo, que não passava de mero agente seu, estava estritamente limitado à consecução dos fins para os quais fora o governo criado, ou seja, a garantia e conservação da vida, da liberdade e da propriedade: o governo não pode exercer um poder absoluto sobre a vida e o patrimônio dos cidadãos, nem privar ninguém de suas propriedades sem consentimento, nem transferir ou delegar seu poder legislativo a nenhum outro órgão ou indivíduo e tem, ainda, que agir dentro dos limites de "leis sancionadas e promulgadas que não visem atingir situações particulares, mas sim que se mostram iguais tanto para o rico como para o pobre, tanto para o favorito da corte como para o lavrador em seu campo".

Quanto ao problema da garantia suprema do Direito Natural, ou seja, sobre a existência de uma autoridade que decida se o Legislativo ou o Executivo transgrediram os limites postos a seu poder, o filósofo inglês, segundo Bodenheimer, não chega a uma conclusão expressa:

Locke en determinado pasaja insinua que el poder judicial há de tener que ser el árbitro final que decida si el Derecho natural há sido violado por un acto legislativo. Por otra parte, al estudiar la separación de poder dentro del Estado, no menciona el poder judicial, y subraya, en cambio, el divorcio del legislativo y ejecutivo. Empero Locke reconoce una garantía ultima del Derecho natural: todo el pueblo, que puede desplazar a su legislativo e incluso resistir al gobierno, en caso de quebrantamiento flagrante, según Locke, si el gobierno ha invadido injustamente la propiedad de los suditos o se ha hecho dueño arbitrario de las vidas y libertades del pueblo. ${ }^{9}$

Assim, a teoria da divisão dos poderes, embora ainda não colocada em termos definitivos dentro do pensamento de Locke, nele encontra alguns de seus alicerces fundamentais que, mais tarde, iriam servir de base para notável construção de Montesquieu. ${ }^{10}$

\footnotetext{
9 BODENHEIMER, Edgar. Teoria del derecho. Traducción en castellano por Vicente Herrero. Mexico: Fondo de Cultura Economica, 1942. p. 168-169.

${ }^{10}$ A respeito da influência que as idéias de Locke exerceram não-só sobre seus contemporâneos, mas também sobre as gerações posteriores, vale transcrever a seguinte passagem de Burns: "Poucos filósofos políticos têm exercido mais influência do que Locke na história do mundo. Não só as suas doutrinas dos direitos naturais, dos governos limitados e do direito de resistência à tirania foram uma fonte importante da teoria da Revolução Francesa, senão que também encontraram pronta aceitação na América. Delas deriva quase todo o fundamento teórico da revolta colonial contra a opressão britânica. Refletem-se com tal evidência na Declaração de Independência dos Estados Unidos que passagens inteiras desse documento dão a impressão de ter sido copiadas do Segundo Tratado" (BURNS, Edward McNall. op. cit., v. 2, p. 599).
} 


\subsection{As idéias políticas de Montesquieu}

Conforme fixa Raymond G. Gettell em sua História das Idéias Políticas, o Espírito das Leis é o primeiro tratado político sistematizado que nasce da inquietação espiritual do século XVIII. ${ }^{11}$

$\mathrm{Na}$ elaboração de sua teoria, Montesquieu inspirou-se nas instituições políticas da Inglaterra e no pensamento de seus grandes teóricos, buscando, outrossim, no sistema político de Roma os precedentes históricos para sua investigação.

O fim primordial de sua obra consiste em expor a natureza e o funcionamento das instituições políticas em geral. Propõe-se a traçar um quadro comparativo do Direito e da política, com base no estudo dos sistemas de vários povos em diversas épocas e, paralelamente, uma teoria comparativa da legislação, de acordo com os diversos tipos de governo.

Assim, ao invés de tentar fundar uma ciência de governo pela dedução pura, seguiu o mérito aristotélico de estudar os sistemas políticos concretos tal como supunha que tivessem funcionado no passado.

Embora ressalte, em grande parte do Espírito das Leis, a influência de Locke e dos outros liberais ingleses, nem sempre os pontos de vista de Montesquieu coincidem com os destes.

Com efeito, em oposição à teoria que considera a lei como um princípio natural imediatamente deduzido dos ditames da razão, Montesquieu amplia o seu conceito, no sentido de incluir, sob sua designação, todas as relações que medeiam entre as causas e seus efeitos. Para se poder determinar o caráter das instituições e da legislação, é necessário um sistema de princípios: das relações entre os Estados nasce o Direito Internacional; das relações entre governantes e governados nasce o Direito Civil, este variável, ao contrário do primeiro, conforme as condições peculiares de cada Estado. Nega, portanto, a existência de uma forma ideal de governo, adequada a todos os povos em quaisquer condições. A forma de governo e o sistema natural de normas jurídicas dependem de todas as circunstâncias que determinam o caráter de um povo e, especialmente, as condições de sua vida. O complexo conjunto dessas influências, de natureza econômica, geográfica, sociológica etc, forma o que ele denomina o espírito das leis.

Vê-se, pois, que Montesquieu é mais um precursor da escola sociológica do Direito do que, como Locke, um adepto ortodoxo da escola do Direito Natural.

\footnotetext{
${ }^{11}$ Cf. GETTELL, Raymond G. História das idéias politicas. 2. ed. São Paulo: Ed. Alba, 1964. p. 293.
} 


\subsection{A teoria da Divisão dos Poderes}

A teoria da divisão dos poderes foi, no pensamento de Montesquieu, fruto da importância que dava ao problema da liberdade humana. Nesse particular, concorda inteiramente com Locke, ao sustentar que a liberdade humana era a meta suprema que uma nação poderia alcançar, girando em torno dessa premissa sua preocupação em construir uma estrutura de governo sob a qual se poderia obter a liberdade e assegurá-la, uma vez conseguida, da melhor maneira possível. Somente um sistema que eliminasse totalmente as possibilidades de abuso de poder, seria hábil para atingir tal desideratum:

Considerando que, em França, o poder soberano ia adquirindo
cada vez mais preponderância frente aos Estados Gerais
(Parlamento), não mais convocados desde 1614 até 1789 ,
enquanto na Inglaterra se verificava o fenômeno oposto,
porque as Câmaras ampliavam cada vez mais seus podres,
limitando correlativamente os da Coroa, Montesquieu julga
necessário assegurar, entre os poderes do Estado, uma
condição de equilíbrio, instaurando-se para esse fim uma
divisão entre os poderes mesmos, para impedir a cada um
deles ultrapassar os limites da própria competência. ${ }^{12}$

Experiência secular tem demonstrado - sustentava o grande pensador - que todo homem investido de autoridade pode dela abusar; para evitar esse abuso é necessário que o poder seja equilibrado pelo poder. Assim, dentro do ponto de vista da liberdade dos cidadãos, a forma mais segura de governo será aquela em que os três poderes, Legislativo, Executivo e Judiciário, estejam estritamente separados, de sorte que cada um deles limite os outros dois.

Dentre os benefícios derivados do sistema de divisão dos poderes, Montesquieu apontava, como principal, a eliminação do perigo de um órgão ultrapassar os limites das próprias atribuições, e, em especial, o perigo da Coroa arrogar-se de prerrogativas do Parlamento. De fato, segundo Montesquieu, uma vez realizada a separação dos poderes, a soberania deixaria de pertencer, ou por outras palavras, de caber a um único, mas sim passaria simultaneamente a todos eles, em condições de absoluta paridade e independência, todos investidos, a igual título, das respectivas competências. Estabelecerse-ia, assim, entre os órgãos fundamentais, um verdadeiro e autêntico equilíbrio (balance de pouvoirs), um servindo de freio ao outro (teoria dos freios e contrapesos), dominados como são por uma recíproca desconfiança ("o poder detém o poder").

${ }_{12}$ GROPPALI, Alexandre. Doutrina de Estado. Tradução de Paulo Edmur de Souza Queiroz. 2. ed. São Paulo: Edições Saraiva, 1962. p. 187. 
A segunda grande vantagem que Montesquieu realça em sua teoria já foi apreciada e diz respeito exatamente à segurança da liberdade individual: fixadas de modo preciso as atribuições de cada um dos poderes, o cidadão é assegurado em sua liberdade não-só pela certeza do direito que regula as relações sociais, como e principalmente porque está ciente de que as atividades dos órgãos do Estado podem ser contidas nos limites de normas jurídicas preconstituídas.

Finalmente, destacava Montesquieu a contribuição de sua teoria para tornar os órgãos do Estado mais adaptados às suas funções próprias, através da especialização e determinação das respectivas competências. ${ }^{13}$

\section{A compreensão da Teoria da Divisão dos Poderes}

3.1. Incorporada ao primeiro governo estabelecido durante a Revolução francesa, de 1789, e adotada com pequenas modificações pela Constituição dos Estados Unidos da América, ${ }^{14}$ a teoria da divisão dos poderes como elaborada por Montesquieu, sem embargo da subsistência dos princípios basilares que a informam, tem sofrido, no tempo, revisões e reajustamentos, objetivando principalmente adaptá-la às exigências da complexa estruturação do Estado de direito moderno.

\subsection{Unidade de poder e divisão de competências}

Nessa linha de idéias, o primeiro ponto que merece ser destacado diz respeito à evolução da mencionada teoria, a partir de sua formulação original, no tocante ao conceito de Poder do Estado e da possibilidade de ser o mesmo divisível.

Montesquieu concebeu a existência de três Poderes independentes entre si, tendo à expressão "Poder", conforme salienta Groppali, um sentido objetivo e material, do qual decorre uma completa divisão, embora teórica, do Estado.

Todavia, como bem lembra Jellinek, o filósofo francês, neste particular, nem fundamentou sua teoria, nem esclareceu de um modo geral a questão referente à unidade de Estado e da sua relação com os Poderes.

${ }^{13}$ Cf. GROPPALI, Alexandre. Doutrina de Estado. Tradução de Paulo Edmur de Souza Queiroz. 2. ed. São Paulo: Edições Saraiva, 1962. p. 187-188.

${ }^{14}$ Dispõe o art. $5^{\circ}$ da Declaração de Direitos de Virgínia de 1776: "O poder executivo e o poder legislativo do Estado devem ser distintos e separados da autoridade judiciária; e a fim de que, tendo também eles de suportar os encargos do povo deles participar, possa ser reprimido todo o desejo de opressão dos membros dos dois primeiros, devem estes em tempo determinado, voltar à vida privada, reentrar no corpo da comunidade de onde foram originariamente tirados; e os lugares vagos deverão ser preenchidos por eleições freqüentes, certas e regulares". 
O próprio Jellinek destaca as dificuldades práticas que esta lacuna acarretou, e como se procurou supri-la:

Los americanos que fueran los primeros em adoptar como sistema constitucional la división de poderes, consideran, sin embargo, que los poderes origináriamente pertencen al pueblo, el cual los entrega a determinados órganos para que lo representen. La primera Constitucion francesa se contradice, pués al propio tiempo que acepta el principio de la division de poderes, delcara que 'La souveraineté est une indivisible, inalienable et imprescritible. Elle appartient a la nation: aucune section de peuple, ni aucun individu ne peut s'en attribuer l'exercice'. Para dar solucion a esta contradiccion, desenvuelve posteriormente Siayes su doctrina del pouvoir constituant que habria de corresponder al pueblo de um modo inalienable, y al que se oponen los poderes particulares como pouvoirs constitués. La unidad originaria de los poderes se habria de mostrar com motivo del ejercicio del derecho a modificar la Constituicion. Las posteriores constituiciones de los estados reconecem expresamente la unidad del Estado mediante uma formula que solo puede ser compreendida si se la considera desde el punto de vista de la evolución de la doctrina de la soberania. ${ }^{15}$

Nota-se, pois, que a doutrina evoluiu no sentido de considerar a consagrada expressão "divisão de poderes" não como pretendendo significar a fragmentação do Estado, mas sim traduzindo o complexo dos órgãos que, dentro de suas atribuições específicas representam o poder do Estado cujas discussões em torno de sua unidade já estão superadas. ${ }^{16}$

Vale, assim, por em relevo a seguinte passagem de Del Vecchio:

Com superior eficácia exprimiu Montesquieu esse conceito (da divisão de poderes) em sua obra sobre o Espírito das Leis: deixa de haver liberdade sempre que na mesma pessoa ou no mesmo corpo o Poder Executivo está reunido ao Legislativo... nem tampouco há liberdade, se o Poder Judiciário não estiver separado do Executivo e Legislativo. Conquanto não seja de todo exata a maneira como trata desta matéria, assiste a Montesquieu o mérito de ter posto em relevo o princípio, impropriamente denominado, da divisão

\footnotetext{
15 JELLINEK, J. Teoria General del Estado. Traducción en castellano por G. Garica Mainez. Mexico: Edição de Manoel de J. Nucamendi, 1936. p. 184.

${ }^{16}$ Id. Ibid., p. 183.
} 
dos Poderes e que com maior rigor se poderia chamar de 'distinção das funções'. ${ }^{17}$

No mesmo sentido é o pensamento de Groppali:

enquanto Montesquieu, antes de tudo, fala sempre em 'Poderes', entendidos mais num sentido objetivo esubstancial, isto é, mais como funções, a doutrina moderna, ao invés, os considera principalmente sob o aspecto subjetivo, ou seja, como um complexo de órgãos determinados destinados pela ordem jurídica ao exercício de competências especiais, dando em resultado que qualquer Poder consista em um complexo de órgãos aos quais se conferem a titulariedade e o exercício de cada uma das funções do Estado. ${ }^{18}$

Como se vê, e apesar de consagrada, mais correta do que "divisão de poderes", mostra-se a expressão “divisão de competências" dentro da Unidade do Estado.

\subsection{As funções primordiais do Estado}

Discutiu-se também sobre quantos seriam os poderes.

Lembra Groppali que alguns autores levaram o número até a dúzia, enquanto que outros o reduziram a dois.

Não nos parece importante a apreciação desses diferentes pontos de vista, uma vez que a divisão original concebida por Montesquieu e já mencionada por Aristóteles ${ }^{19}$ parece expressar adequadamente as funções primordiais do Estado.

A corrente à qual se filia o próprio Groppali sustenta a existência de quatro poderes, alinhando, ao lado da Magistratura e o Parlamento, o chefe de Estado e o Governo. Todavia, o próprio mestre italiano reconhece a íntima identidade e a natureza comum das funções que ele denomina de Poder político ou de Governo e Poder administrativo, afirmando que as mesmas não podem deixar de prosseguir unidas entre si, porquanto, se a primeira se encontra na predeterminação dos fins do Estado, a segunda serve à atuação política destes. ${ }^{20}$

\footnotetext{
${ }_{17}$ DEL VECCHIO, Giorgio. Teoria do Estado. Tradução de Antonio Pinto de Carvalho. São Paulo: Edições Saraiva, 1957. p. 55-56.

${ }^{18}$ Id. Ibid., p. 188-189.

${ }^{19}$ Cf. GROPPALI, Alexandre. op. cit., p. 187.

${ }^{20}$ Cf. Id. Ibid., p. 189-190.
} 
É o caso, pois, de ficar com aqueles que entrevêm no Estado apenas três funções com características suficientemente peculiarizadas para atenderem, dentro da idéia já fixada, ao conceito de Poder: a executiva ou administrativa, a legislativa e a judiciária.

\subsection{O conteúdo das funções primordiais do Estado}

Cabe-nos agora, ainda que sumariamente - pois a apreciação desse aspecto da teoria da divisão dos poderes, por si, ensejaria todo um tratamento específico - examinar a tônica fundamental de cada uma das três funções essenciais do Estado.

A função legislativa, dentro do Estado de Direito, é geralmente confiada, para usarmos uma expressão mais genérica, aos órgãos de representação popular. Tal função tem por escopo fundamental fixar o ordenamento jurídico do Estado, mediante aprovação, em caráter geral e abstrato, de leis destinadas a regular a organização do próprio Estado, as relações entre este e os cidadãos e ainda as relações destes últimos entre si.

A função executiva, por seu turno, é que representa maior multiplicidade de aspectos, justificando assim o conceito 'residual' que Del Vecchio lhe atribuiu, ao afirmar que ela abrange todas as atividades do Estado com exceção da legislativa e da judiciária. ${ }^{21}$

Finalmente, a função judiciária visa a tutelar a ordem jurídica, isto é, a obter em casos concretos a declaração do direito e a observância do ordenamento jurídico, mediante a resolução, por parte deste Poder, das controvérsias que surgem tanto entre particulares, quanto entre particulares e entes públicos. ${ }^{22}$

\subsection{Delegação de Poderes}

Não é nossa intenção adentrar em detalhes ao problema da delegação de competências, por entender que o mesmo, em sua essência, somente pode ser adequadamente examinado à luz do ordenamento jurídico-positivo de cada Estado e das respectivas condições políticas em um dado momento histórico.

Não podemos, entretanto, deixar de mencionar que a elaboração original de Montesquieu vedava expressamente tal expediente e que este princípio, com maior ou menor rigor, tem sido incorporado às constituições democráticas. ${ }^{23}$

${ }^{21}$ Cf. GROPPALI, Alexandre.Doutrina de Estado. Tradução de Paulo Edmur de Souza Queiroz. 2. ed. São Paulo: Edições Saraiva, 1962. p. 65-66.

${ }^{22}$ Id. Ibid., p. 196.

${ }^{23}$ A competência outorgada ao Presidente da República para editar medidas provisórias, bem como para elaborar leis delegadas são hipóteses de delegação expressamente consentidas por nosso ordenamento jurídico-positivo (arts. 62 e 68 da Constituição Federal). 


\subsection{Inter-relação entre os Poderes}

Como vimos, dentro do pensamento de Montesquieu os poderes deveriam ser exercidos por órgãos distintos, rigorosamente separados entre si, a fim de garantir o recíproco equilíbrio e impedir a eventual hipertrofia de um ou alguns deles. Entretanto, essa concepção não é, modernamente, levada ao extremo de configurar as três categorias de órgãos como compartimentos estanques; por isso estaria em frontal contradição com a unidade viva do organismo estatal.

Com efeito, dentro da complexidade do Estado contemporâneo em suas inúmeras correlações e implicações, a teoria da divisão dos poderes passou a ser entendida "não mais mecanicamente, no sentido de uma rígida separação de órgãos com funções individuadas, mas, de um lado, como especificação de órgãos e atribuições de funções expressas em formas diferentes (lei, decreto, sentença) e, de outro lado, como coordenação de órgãos distintos na unidade do Estado, a qual encontrava sua expressão no poder político exercido pelo governo com a maior liberdade de apreciação e atividade". ${ }^{24}$

Nessa ordem de idéias, podemos entrever, sem embargo das atribuições típicas reservadas a cada poder, uma crescente permeabilidade e interpenetração entre os mesmos, imposta pelas próprias contingências da vida social. Quase todas as constituições democráticas modernas, sem prejuízo e - o que é importante - sem quebra do princípio da separação dos poderes, pressupõem hipóteses em que os órgãos legislativos exercem funções administrativas ou mesmo judiciais e outras em que o Executivo, ainda que por exceção, assuma poderes legislativos, e assim por diante. ${ }^{25}$

\subsection{Hierarquia entre os Poderes}

$\mathrm{O}$ último ponto a ser tratado diz respeito à questão da hierarquia entre os poderes do Estado.

Bodenheimer, referindo-se à história jurídica da Inglaterra, lembra que o jurista Edward Coke, mais de um século antes de Montesquieu, sustentava a tese da

${ }^{24}$ GROPPALI, Alexandre. Doutrina de Estado. Tradução de Paulo Edmur de Souza Queiroz. 2. ed. São Paulo: Edições Saraiva, 1962. p. 190.

${ }^{25}$ Em diversos preceitos da Constituição Federal pode ser identificada a atribuição de competências "atípicas". Sirvam de exemplo os seguintes: a) art. 51, I e II - competência do Senado Federal para "processar e julgar" o Presidente e o Vice-Presidente da República nos crimes de responsabilidade, bem como os Ministros de Estado e os Comandantes da Marinha, do Exército e da Aeronáutica nos crimes de mesma natureza conexos com aqueles; b) art. 62 - competência do Presidente da República para, em casos de relevância e urgência, adotar medidas provisórias; c) art. 96, I, "a" - competência dos tribunais para elaborar seus regimentos internos (normas complementares à legislação processual). 
supremacia do Judiciário, sob fundamento de que existia um Direito Natural imutável que nenhum rei ou Parlamento poderia alcançar. Coke dizia que os tribunais da "common law" tinham autoridade superior à do Parlamento, de tal sorte que uma lei, desde que contradissesse as regras reconhecidas do "direito comum e da razão" era totalmente nula, não devendo ser tomada em consideração pelo juiz. ${ }^{26}$

Mais tarde (meados do século XVIII) e com maior precisão, por influência dos famosos Comentários sobre as Lei da Inglaterra, de William Blackstone, passou a prevalecer a doutrina da supremacia do legislativo, aceita sem restrições por Locke, Rousseau, Kant e encontrando vigorosos prosélitos em autores modernos, entre os quais Del Vecchio, que sustenta seu ponto de vista, partindo da premissa de que todo ato particular de qualquer órgão do Estado deve referir-se a uma máxima geral como seu pressuposto lógico e que a determinação dessas máximas é função peculiar dos legislativos.

Sem embargo do respeito que merece tal ponto de vista, entendemos que não espelha a melhor doutrina, como superiormente destaca Miguel Reale: "impossível é reconhecer o primado do poder legislativo, pois 'função legislativa' e 'poder legisferante' não coincidem, sendo a lei geralmente o resultado de uma colaboração harmônica de poderes e esta função vai cada vez mais assumindo uma feição eminentemente técnica". ${ }^{27}$

E, com efeito, aceitando a feliz síntese de Groppali, parece-nos inevitável a prevalência da tese da paridade dos Poderes: "quando se prescinde da preeminência que, por seu mérito, passam a adquirir determinados homens em certos momentos, e quando se observa a questão pelo seu lado estritamente jurídico, não se pode deixar de aderir à tese da paridade, dada a igual importância de suas funções e a necessidade da sua coordenação sobre um mesmo plano em posição paritária". ${ }^{28}$

\section{Conclusão}

4.1. Ao término desta modesta investigação, através da qual, sem ter a pretensão de analisar em profundidade todos os aspectos da teoria da divisão dos poderes, procuramos dar uma visão panorâmica de suas origens históricas, e de sua configuração à luz da concepção moderna de Estado, assim podemos sintetizar nossas conclusões:

4.1.1. Sob o ponto de vista histórico, a teoria da divisão dos poderes elaborada por

${ }^{26}$ BODENHEIMER, Edgar. Teoria del derecho. Traducción en castellano por Vicente Herrero. Mexico: Fondo de Cultura Economica, 1942. p. 174.

${ }^{27}$ REALE, Miguel. Teoria do Direito e do Estado. 2. ed. São Paulo: Liv. Martins editora, 1960. p. 321.

${ }^{28}$ GROPPALI, Alexandre. op. cit., p. 191. 
Montesquieu, no século XVIII, está intimamente ligada à luta pela consecução de um dos mais importantes ideais políticos da época, como seja, a destruição do absolutismo e a garantia da liberdade individual.

4.1.2. Notável, em seus princípios fundamentais, como solução jurídica para o problema do estabelecimento e da manutenção da democracia, a teoria da divisão dos poderes, ao longo dos tempos, tem exercido poderosa influência sobre os ordenamentos jurídicos positivos dos Estados modernos.

4.1.3. A teoria da divisão dos poderes sofreu, desde sua formulação original, revisões e reajustamentos, de sorte que, modernamente, sua compreensão implica no reconhecimento de que:

a) somente em um sentido impróprio é possível falar-se em divisão de poderes, uma vez que o Poder do Estado é unitário e indivisível, devendo, não-obstante, dentro do sistema democrático de governo, ser exercido por um conjunto de órgãos Legislativo, Executivo e Judiciário - cada qual dentro dos limites de sua prefixada competência. Assim, mais corretamente pode-se falar, em lugar de divisão de Poderes, em divisão de competências;

b) a divisão das funções essenciais do Estado em legislativa, executiva e judiciária visa apenas caracterizar as atribuições típicas de cada uma delas, não-obstando a existência de permeabilidade de interpenetração entre as mesmas, decorrentes da própria complexidade da realidade social de nossos dias;

c) no moderno Estado de Direito, as suas funções essenciais estão colocada no mesmo nível de importância, sem supremacia de uma sobre as outras.

São Paulo, novembro de 2007.

\section{Referências}

ALTAVILA, Jayme de. Origem dos direitos dos povos. São Paulo: Edições Melhoramentos, 1960.

BODENHEIMER, Edgar. Teoria del derecho. Traducción em castelhano por Vicente Herrero. México: Fondo de Cultura Economica, 1942.

BURNS, Edward McNall. História da civilização ocidental. 2. ed. Porto Alegre: Ed. Globo, 1959. DEL VECCHIO, Giorgio. Teoria do Estado. Tradução de Antonio Pinto de Carvalho. São Paulo: Edições Saraiva, 1957. 
GETTELL, Raymond G. História das idéias políticas. 2. ed. São Paulo: Ed. Alba, 1964.

GROPPALI, Alexandre. Doutrina de Estado. Tradução de Paulo Edmur de Souza Queiroz. 2. ed. São Paulo: Edições Saraiva, 1962.

JELLINEK, J. Teoria General del Estado. Traducción en castelhano por G. Garcia Mainez. Mexico: Edição de Manoel de J. Nucamendi, 1936.

LIMA, Manuel de Oliveira. História da civilização. 11. ed. São Paulo: Edições Melhoramentos, s.d.

PIRES, Herculano. Os filósofos. São Paulo: Editora Cultrix, 1960.

RÁO, Vicente. O Direito e a vida dos direitos. São Paulo: Editora Max Limonad, 1952.

. Estudo sobre delegação de poderes. In: Estudos Jurídicos em Honra de Soriano Neto. Recife: MEC - Universidade do Recife, 1962.

REALE, Miguel. Teoria do Direito e do Estado. 2. ed. São Paulo: Livraria Martins Editora, 1960.

REVISTA BRASILEIRA DE ESTUDOS POLÍTICOS. Belo Horizonte: Imprensa Universitária, 1956- . Semestral.

THOMAS, Henry. Vidas de grandes filósofos. Porto Alegre: Ed. Globo, 1960. 